\title{
An Empirical Investigation of Mathematics Learning Approaches and Metacognitive A wareness of Students
}

\author{
Ahsen Seda Bulut* \\ Social Sciences Vocational School, Kirsehir Ahi Evran University, Kirsehir, Turkey.
} ORCID: 0000000321927799

Article history

Received:

22.10.2020

Received in revised form: 09.03.2021

Accepted:

28.03.2021

Key words:

Mathematics learning approach;

Metacognitive awareness; Metacognition.
The goal of this study is to examine the mathematics learning approaches and metacognitive awareness of 6th, 7th and 8th grade students with regard to some variables. This is a quantitative study conducted in a survey model. In the 2018-2019 academic year, the working group was secondary school students in the public schools in Central Anatolia region 6.7.8. It consists of 330 (166 girls, 164 boys) students studying at the grade level. As the data collection tools, Göktepe-Y1ldız and Özdemir's (2018) "Mathematics Learning Approach Scale", which was originally developed by Schraw and Dennison (1994); The Metacognitional Awareness Inventory developed by Akın, Abacı and Çetin (2007) was utilized. According to the empirical findings, for sixth, seventh, and eighth grade students, scores for deep and strategic learning approaches are above the medium level, whereas scores for surface approach is below the medium level. In addition, it has been determined that mathematics learning approaches differ significantly according to gender, grade level and mathematics achievement. As a consequence of the analysis, it was seen that students' levels of metacognitive awareness were high. The levels of metacognitive awareness did not differ by gender, but differed significantly by grade level and mathematics achievement. In addition, while there exists a positive and statistically significant relationship between deep learning and strategic learning approaches and metacognitive awareness no statistically significant relationship was found between the surface learning approach and the metacognitive awareness.

\section{Introduction}

Metacognition is expressed as thinking about thinking in the most general sense (Blakey \& Spence, 1990). While the acquisition and use of information are explained by the cognitive process in individuals, the fact that the individual is aware of herself (what he/she does, how he/she does it) and the process (what he/she does in what order, what he/she gets) contains awareness. This awareness reveals the concept of metacognition (Çakıroğlu, 2007). Metacognition is an older phenomenon though it was proposed by Flavell (1979). Flavell (1979) considers metacognition as knowledge stemming from the obtained experiences of an individual when utilizing the cognitive process. The concepts of cognition and metacognitive

\footnotetext{
* Correspondency: ahsenseda@ahievran.edu.tr
} 
are interrelated but independent concepts. While cognition means awareness and understanding of anything, metacognitive is to know how to learn it (Senemoğlu, 2005). That said, cognition is the sum of processes and strategies used to process information, whereas metacognition is what an individual knows about his/her cognitions and the ability to control it as well (Forrest-Pressley \& Waller, 1984). Metacognitive awareness is the individual's awareness of what he/she knows, controlling her/his own mental processes, estimating, taking responsibility for learning, evaluating, planning and monitoring his/her learning, and using strategies to manage his/her knowledge (Bağçeci, Döş \& Sarıca, 2011; Brown, 1980; Dunslosky \& Thiede, 1998; Meichenbaum, 1985). Although there exist different definitions for the components of metacognition, it can usually be categorized under two main components: (i) knowledge of cognition and (ii) regulation of cognition. On one hand, thre is knowledge of cognition that implies what individuals know about their own cognition or generally about cognition. It contains three different types of metacognitive awareness: declarative, procedural, and conditional knowledge. On the other hand, there is regulation of cognition which means a group of activities helping students to check their own learning. Regulation of cognition refers to the behaviours that control and use the knowledge of cognition and includes five sub-elements: (i) planning, (ii) managing information, (iii) monitoring, (iv) debugging and (v) evaluation (Akın, 2006). Metacognitive awareness implies an individual is aware of how he/she thinks and how he/she learns. Metacognitive awareness enables an individual to realize what he/she does not understand and to become more motivated to eliminate the factors that hinder understanding (Hacker, 1998).

Taking a closer look at the empirical literature, one may observe that many studies have tried to explain which variables affect metacognition and metacognitive awareness. Within this scope, researchers focused on (i) gender (Y1ld1z, Baltac1 \& Kuzu, 2018), (ii) learning styles (Baltacı, Yıldız \& Özçakır, 2016), (iii) academic and mathematical achievement (Desoete, Roeyers, \& Buysse, 2001; Young \& Fry, 2008), and (iv) enhancing in metacognition (Volet, 1991).

As the previous studies in the empirical literature indicate students having relatively higher levels of metacognitive awareness are more successful than other students (Akın, 2006; Altındağ \& Senemoğlu, 2013; Brown, 1980; Garner \& Alexander, 1989; Lee, Teo, \& Bergin, 2009; Martini \& Shore, 2008; Pressley \& Ghalata, 1989; Uckun, Demir, \& Yüksel, 2012; Vadhan \& Stander, 1994). Because an individual's metacognitive awareness makes planning, implementing, developing and evaluating the learning process more efficient (Atıok-Başer \&Yükseltürk, 2019). In this research, the relationship between mathematics learning approaches and metacognitive awareness was investigated.

The concept of learning approach means how the student achieves her/his academic tasks and eventually affects the nature of the learning outcomes (Biggs, 1994). Marton and Saljo (1976a, 1976b) introduce two types of learning approaches, namely deep learning and surface learning. In these studies, it is stated that details may lead to miss the essence of the subject due to the anxiety of questions in surface learning and that there exists an effort to understand what is really being told in deep learning. Marton (1983) and Ramsden (1988) emphasize why the particular context is crucial in deciding if a deep or surface approach to learning is utilized and denoted that the learning approach should be considered as a response to the situation instead of a style-like, stable trait of a student. But, Entwistle (1981) and Schmeck (1988) argue students have a predilection to use deep or surface approaches proceeding for different cases and call it a learning orientation. Besides, Biggs (1987) argues with them and stresses even though students may alter their learning approaches with regard to the demand for each 
case, and this change is influenced by students' predisposition to change, which is in turn affected by personal characteristics, namely ability.

In the deep learning approach, the individual tends to seek meaning and form (Reid, Duvall \& Evans, 2007). Understanding where the information comes from, knowing the usage areas, establishing a relationship between them (Darlington, 2011) to understand and learn about the subject is essential, and there is a coherent whole (Ramsden, 2000) as well as dealing with the nature of work (Newble \& Entwistle, 1986). Deep approach was defined as "intention to understand, vigorous interaction with content, relate new ideas to previous knowledge, relate concepts to everyday experience, relate evidence to conclusions, examine the logic of the argument" by Byrne, Flood and Willis (2002, p. 29).

A surface approach is one in which students attempt to rote learn material in order to subsequently reproduce it, while a deep approach is one in which they seek meaning in order to understand (Trigwell \& Prosser, 1991). The surface approach arises from an intention to get the task out of the way with minimum trouble, while appearing to meet course requirements. Low cognitive-level activities are used, when higher level activities are required to do the task properly (Biggs, 2011). The surface approach is linked to low motivation and the use of memorization strategies, resulting in rote learning (Biggs, 1988). Students who prefer this approach only intend to meet their task requirements, memorize information for evaluation, and evaluate learning as an external challenge (Ramsden, 2000). It poses a difficulty in recognizing the consistency between sources of information and thus they cannot associate it with previous information (Beydoğan, 2007).

A student can use both deep and surface learning approaches simultaneously to be successful (Newble \& Enwistle, 1986). In this case, Ramsden (1979) introduced a new learning approach called strategic learning approach. As a mixed approach in strategic learning approach (Bigss, 1993; Entwistle 1991; Harlen \& James, 1997); students effectively manage space and time to obtain highest grades with minimal effort (Biggs, Kember, \& Leung, 2001). Students, on the other hand, address the issue of learning with the intention to succeed without attempting to search for or create meaning (Reid, Duvall, \& Evans, 2007). The student tries to get high grades, uses appropriate materials to facilitate learning and uses resources to accelerate his perceptions while working (Beydoğan, 2007). In addition, students are aware of the tips to increase their chances of academic success, of the evaluation criteria and of the means to evaluate (Heikkila \& Lonka, 2006). It can be difficult to distinguish these students from those who use a surface or deep approach. Because these students refer to? many other strategies with high anxiety. They choose the approach that allows them to get higher scores (Makinen, 2003). They can make attempts such as paying attention to the clues given by the teachers, turning to the questions asked in the previous exams, and trying to make a good personal impression on the people they believe will have an impact on the evaluation (Newble \& Entwistle, 1986).

The types of learning approaches and what kind of behaviours arise as a result of these approaches have been examined by the researchers. In addition, factors affecting students' learning approaches are also explored. Learning approaches are formed as a result of all the factors such as the teaching methods used by the teacher, attitude towards the student, the level of student's readiness, interest in the subject and the way it is evaluated (Ellez \& Sezgin, 2002). The learning approach explains students' learning ways, not their characteristics (Biggs, 2011). From this point of view, learning approach should not be seen as a constant feature. Therefore, by examining different variables that affect learning approaches; teaching 
method (Aral, Gürsoy \& Can-Yaşar, 2012; Biggs, 1987; Ellez \& Sezgin, 2002; Trigwell, Prosser \& Waterhouse, 1999), past life, grade level, achievement level, conditions of the teaching-learning environment (Bulut, Y1ld1z, \& Baltac1, 2020; Cuthbert, 2005; Ekinci, 2009; Marton \& Saljo, 1997; Mayya, Rao \& Ramnarayan, 2004; Selcuk, Caliskan \& Erol, 2007; Trigwell \& Prosser, 1991), have been reported to be related to variables. Bulut, Yildiz, and Baltac1 (2020) revealed that there are significant differences according to the gender variable in their studies. It was reported that girls resort to strategic learning significantly more than boys. Özgür and Tosun (2012), on the other hand, concluded in their study that boys prefer surface learning in a way that differs significantly from girls. Based on these different findings in the extant literature, in addition to class level and achievement level, the gender variable will also be investigated in this study.

One of the important variables that influences students' preferences regarding learning approaches is the subject content. Since students show different learning approaches in different subject areas, they require research to be field-oriented (Entwistle, 1997; Lucas, 2001). Studies on the subject of learning approaches conducted in Turkey have increased in recent years. However, when these are evaluated on a field basis, the studies carried out for the mathematics course are found as limited (İlhan, Çetin \& Kılıç, 2013; Göktepe-Yıldız \& Özdemir, 2018; Bulut, Y1ldız, \& Baltac1, 2020). In both studies (İlhan et al., 2013; GöktepeY1ldiz \& Özdemir, 2018), researchers have developed a measurement tool that will enable them to measure students' mathematical learning approaches validly and reliably. Bulut et al. (2020) compared the mathematics learning approaches of gifted and non-gifted students in their research. Unlike the limited number of studies on this subject, this study examined students' mathematical learning approaches together with their metacognitive awareness. Therefore, in this study, the relationship and interaction of independent variables such as gender, grade level and academic achievement, which are of great importance in mathematics education and which have a close relationship with learning, can be influential in learning approaches,. To this end, the sub-problems of the present research are as below:

(1) In students' mathematical learning approaches, is there any statistically significant difference according to (a) gender, (b) class level, and (c) mathematics scores?

(2) In the metacognitive awareness levels of students, is there any statistically significant difference according to (a) gender, (b) class level, and (c) mathematics scores?

(3) Does the level of metacognitive awareness predict math learning approaches?

\section{Method}

In this section, information is given about the model of the research, participants, data collection, the process and analysis of the research.

\section{Model of the research}

This is a descriptive study and survey model was used to define an existing situation about students' mathematics learning approaches and their metacognitive awareness and to reach general evaluations. Descriptive research aims to describe an existing situation as it exists without any experimental action (Karasar, 2005). In survey models, individuals who are subjects in the research are tried to be defined within their own conditions and their characteristics are determined (Köse, 2013). 


\section{Working sample}

330 students, viz. 6th, 7th and 8th grade students, participated in the research in 20182019 academic year. 5th grade students were first intended to be included, but expert opinions were taken and it was decided that the measurement tools were not suitable for this grade level. For this reason, it was decided that only 6th, 7th, and 8th grade students should participate in the study. Data on students were obtained from two secondary schools in a province in Central Anatolia. In the study, the convenience sampling method was used to determine the study sample because of time and workforce restrictions. For this method, the sample is chosen from an appropriate and quickly reachable population because of time, labour, and economic limitations (Büyüköztürk, 2015). School names are coded as A secondary school and B secondary school. The students participating in the study consist of 166 girls and 164 boys. The distribution of these students by grade level is as follows Grade 6 is with $134(40.3 \%)$ students, grade 7 is with $64(19.4 \%)$ students, grade 8 is with 132 $(40.3 \%)$ students.

Table 1. Number of students participating in the research according to grade level

\begin{tabular}{lllll}
\hline & \multicolumn{3}{c}{ Class } & \\
\cline { 2 - 4 } 6th grade & 7 th grade & 8 th grade & 183 \\
A S. School & 18 & 63 & 102 & 147 \\
B S. School & 116 & 1 & 30 & 330 \\
Total & 134 & 64 & 132 & 32 \\
\hline
\end{tabular}

\section{Data collection tools}

\section{Mathematics learning approach scale}

As one of the data collection tools, "Mathematics Learning Approaches Scale" of Göktepe-Yıldız and Özdemir (2018) was used.

Mathematics Learning Approach Scale consists of 33 items and three sub-dimensions which are deep learning, surface learning and strategic learning. The scores obtained from the subdimensions of the scale are interpreted independently. High scores from the lower dimensions indicate students' tendency to choose that size in math; low scores show that students have low tendency to choose that size in math. For example, a student's "deep learning approach" may be high and the "strategic learning approach" may be low. In the scale, the item "I will try to memorize if I do not understand the solutions of the questions while I am working on math" is in the form of "surface learning". The article "I think and try to understand each part in detail while learning a mathematics topic" was included in the "deep learning" dimension, and "I look for ways to be successful in mathematics lesson by preparing my own working environment" was included in the strategic learning dimension. The scale is a 5-point Likert type scale with "I strongly disagree $=1$ " and "I strongly agree $=5$ ". The three sub-factors account for $41,048 \%$ of the whole variance. This ratio is acceptable (Scherer, Luther, Wiebe \& Adams, 1988). Item factor load values range from .323 to .713 (Göktepe-Yıldız \& Özdemir, 2018).

Firstly, in order to decide which statistical tests to be performed, skewness - kurtosis values were examined regarding whether the data showed normal distribution. As a requirement of the scale, skewness and kurtosis values of the sub-dimensions were also examined. Skewness (-.593) and kurtosis (.677) for the entire test; skewness (-.581) and kurtosis (.230) for the deep sub-dimension; skewness (-.726) and kurtosis (-.186) for the strategic sub-dimension; skewness (.203) and kurtosis $(-.180)$ for the surface sub-dimension were determined. Since 
these values are between +1 and -1 values, it can be said that the data distribution in the study is normal distribution (Hair, Black, Babin, Anderson \& Tatham, 2013). Therefore, parametric tests were used in the analysis of the research problems in the continuation of the study.

In order to determine the reliability level of the Mathematics Learning Approaches scale used in the study, reliability analysis was performed and Cronbach's alpha coefficient was obtained. For this study the cronbach alpha reliability coefficient of the whole scale is .91 . Cronbach alpha reliability coefficients related to sub-dimensions are .88 for the deep learning approach, .92 for the strategic learning approach and .79 for the surface learning approach. In general, this scale is sufficiently reliable since scales with a reliability coefficient of .70 and above are considered reliable (Fraenkel, Wallend \& Hyun, 2012).

\section{Metacognitive awareness inventory (MAI)}

Metacognitive Awareness Inventory (MAI) was developed by Schraw and Dennison (1994) and has been adapted to Turkish by Akın, Abacı and Çetin (2007). A total of 52 items were accompanied by a 5-point response scale ranging from "strongly agree" to "strongly disagree". MAI consists several subscales assessing knowledge of cognition (declarative knowledge, procedural knowledge, conditional knowledge) and regulation of knowledge (planning, monitoring, evaluation, debugging strategies and management information strategies).

The internal consistencies of the MAI, was found .95 for the entire scale, and for subscales were found ranged between .93-.98. Findings also exhibited the corrected item-total correlations ranged from .35 to .65 . For each factor and each item, the differences between mean scores of upper $27 \%$ and lover $27 \%$ groups are significant. Test-retest reliability coefficient of MAI over three-week period was .95. (Akın et al., 2007). While the highest score that can be obtained from the scale is 260 , the lowest score is 52 . There are no negative items in the scale, and high scores indicate a high level of metacognitive awareness. By dividing the total score obtained from the scale to the number of items, a conclusion can be reached about the level of metacognitive awareness of the person concerned. It can be said that individuals who receive less than 130 points from MAI have low metacognitive awareness, whereas those who receive more than 130 points have high metacognitive awareness.

Factor analysis results on the original form of the inventory reveal that the total variance explained is $65 \%$ and factor loads vary between .31 and .70 . Internal consistency coefficients also vary between .88 and .93 for scale sub-dimensions.

In this study; firstly, in order to decide which statistical tests to be performed, skewness kurtosis values were examined regarding whether the data showed normal distribution. The skewness value of the whole test is -.252 kurtosis value, -043 . Since these values are between +1 and -1 values, it can be said that the data distribution in the study is normal distribution (Hair et al., 2013).To this end, parametric tests were used in the analysis of the research problems in the rest of the study. In addition, the cronbach alpha reliability coefficient of the whole scale was found to be .96 in the calculation for reliability.

\section{Data collection process}

The researchers had on-site visits to the secondary schools designated in the city centre and explained the research to the administrators, and the scale forms were applied to 
the students with the support of these individuals. Before the scale was applied, the researcher talked about the content and scope of the scale and made the necessary explanations. Only with the participation of volunteer students, the implementation took 1 course hour (40min). Scale forms obtained from students were systematically numbered and analysed.

\section{Data analysis}

The data of the research were analysed by running SPSS 23 package program. As a result of the normality analyses, it was observed that the data were distributed parametrically. Thus, t-Test, One-Way Variance Analysis, Pearson correlation analysis and simple linear regression analysis were used for independent samples in the analysis of the data collected in the research. In the research, the level of significance in statistical processes was determined as .05. In the research questions in which variance analysis was made, firstly, Levene Homogenity Test was applied. According to test results, since p> .05, the data has a homogeneous distribution and variance analysis shows a suitable structure. Accordingly, in the analysis of the relevant variables, Tukey HSD test, which is one of the Post Hoc techniques, was applied since it was observed that the variances were homogeneous according to the Levene Homogeneity Test result ( $p>.05)$.

\section{Results}

In this section, it has been examined whether students' mathematics learning approaches and their metacognitive awareness differ according to gender, grade level and mathematics achievement regarding the sub-problems of the research. In addition, the relationship between students' mathematical learning approaches and metacognitive awareness were examined.

\section{Results regarding the first sub-problem}

Table 2. Descriptive statistics on mathematics learning approaches

\begin{tabular}{lllll}
\hline Learning Approaches & Min & Max & $\overline{\mathrm{X}}$ & sd \\
\hline Deep & 11 & 55 & 39.15 & 10.14 \\
Strategic & 11 & 55 & 40.54 & 10.81 \\
Surface & 11 & 55 & 32.44 & 8.91 \\
\hline
\end{tabular}

When the results given in Table 2 are analysed, it is seen that the students' highest average score is in the strategic learning approach. There are 3 sub-dimensions in the scale. The minimum score to be taken from each sub-dimension is 11 and the maximum score is 55 . When the average point value is evaluated as 33 , it is seen that the preference scores for strategic $(\overline{\mathrm{X}}=40.54)$ and deep learning approaches $(\overline{\mathrm{X}}=39.15)$ are above average; surface learning approach is slightly below average.

Table 3. Descriptive statistics on metacognitive awareness

\begin{tabular}{lllll}
\hline Metacognitive Awareness Sub- dimensions & Min & Max & $\overline{\mathrm{X}}$ & $\mathrm{Sd}$ \\
\hline Declarative knowledge & 8.00 & 40.00 & 29.42 & 6.53 \\
Procedural knowledge & 4.00 & 20.00 & 14.65 & 3.51 \\
Conditional knowledge & 5.00 & 25.00 & 18.37 & 4.38 \\
Planning & 7.00 & 35.00 & 25.36 & 5.93 \\
Monitoring & 8.00 & 40.00 & 28.83 & 7.00 \\
Evaluation & 6.00 & 30.00 & 21.66 & 5.17 \\
Debugging & 5.00 & 25.00 & 18.26 & 4.30 \\
Managing information & 9.00 & 45.00 & 32.44 & 7.42 \\
TOTAL & 52 & 260 & 189.04 & 39.9 \\
\hline
\end{tabular}


Table 3 shares each sub-dimension in the scale and the scores obtained from them. The total score average of the students received from MAI is $\overline{\mathrm{X}}=189.04$. Accordingly, considering that the average score is 130 , students' metacognitive awareness is high. It was observed that the students got the most points in the MAI sub-dimensions i.e., the "Managing information" subdimension while the lowest score was in the "Procedural knowledge" sub-dimension.

a) Table 4 shows the results of independent sample t-test regarding whether students' mean scores on mathematics learning differ according to gender.

Table 4. Independent sample t test results of mathematical learning approaches by gender

\begin{tabular}{llllllll}
\hline Learning approaches & Gender & $\mathrm{N}$ & $\bar{X}$ & $\mathrm{sd}$ & $\mathrm{df}$ & $\mathrm{t}$ & $\mathrm{p}$ \\
\hline Deep & Girl & 166 & 40.3 & 9.6 & 327 & 2.26 & .024 \\
& Boy & 164 & 37.8 & 10.5 & & & \\
Strategic & Girl & 166 & 47.2 & 9.8 & 328 & 3.81 & .000 \\
& Boy & 164 & 38.3 & 11.3 & & & \\
Surface & Girl & 166 & 31.3 & 8.1 & 327 & 2.27 & .024 \\
& Boy & 164 & 33.5 & 9.5 & & & \\
\hline
\end{tabular}

As a requirement of the scale used, analysis was made for 3 sub-dimensions. Accordingly, the scores of the students in all sub-dimensions show a significant difference according to the gender variable $(\mathrm{p}<.05)$. While this difference is in favour of female students in students who show a deep and strategic approach, the significant difference is in favour of male students in students who show a surface approach. In other words, while female students show deep and strategic learning approaches more, boys prefer surface learning approach.

b) In the first sub-problem of the research, the question of whether there exists significant difference in the mathematical learning approaches of the students according to the grade level was investigated. The analyses made for this question are as follows.

Table 5. Descriptive statistics about grade level

\begin{tabular}{lllll}
\hline Learning approaches & Grade & $\mathrm{N}$ & $\bar{X}$ & $\mathrm{sd}$ \\
\hline Deep & 6 & 134 & 41.83 & 9.42 \\
& 7 & 64 & 36.81 & 11.88 \\
Strategic & 8 & 132 & 37.34 & 9.63 \\
& 6 & 134 & 43.53 & 9.90 \\
Surface & 7 & 64 & 38.37 & 12.21 \\
& 8 & 132 & 38.55 & 10.34 \\
& 6 & 134 & 29.70 & 8.15 \\
\end{tabular}

In Table 5, descriptive statistics of students' mean scores of mathematics learning approaches according to grade level are given. In the deep learning approach sub-dimension, the scores are ranged from high to low as Grade 6, Grade 8 and Grade 7. The same ranking is also used in the strategic learning approach. In the surface learning approach, the rank is 7 th grade, 8th grade and 6th grade from high to low. In all grade levels, it was seen that the students preferred strategic learning the most then mathematics learning approaches and the surface learning approaches the least. 
Table 6. ANOVA results of mathematics learning approaches sub-dimensions according to the grade level

\begin{tabular}{lllllll}
\hline & Sum of squares & df & Mean square & F & $\mathrm{p}$ & $\eta^{2}$ \\
\hline Within groups & 8.005 & 2 & 4.002 & 7.025 & .001 & 0.95 \\
Between groups & 185.719 & 326 & .570 & & & \\
Total & 193.723 & 328 & & & & \\
\hline
\end{tabular}

Whether the mathematics learning approaches of students change according to their grade levels was tested by one-way analysis of variance.

"Tukey HSD" test, one of the post-hoc tests, was carried out to determine from which grade level the meaningful difference in students' mathematics learning approaches originated. According to the results obtained, there is a significant difference between 6th grade-7th grade and 6th grade-8th grade levels in all sub-dimensions of learning approaches. While this difference is in favour of 6th grades in deep and strategic learning approach, 8th grades are in favour of surface learning approach. According to these results, 6th grade students prefer deep and strategic learning further compared to 7 th grade and 8th grade students.

c) In the first sub-problem of the study, the question of whether there is a significant difference in mathematical learning approaches of students according to mathematics achievement was investigated. The analyses made for this question are as follows.

Table 7. Descriptive statistics of students' scores regarding mathematics learning approaches according to mathematics achievement

\begin{tabular}{|c|c|c|c|c|}
\hline & Mathematics Achievement & $\mathrm{N}$ & $\overline{\mathrm{X}}$ & $\mathrm{sd}$ \\
\hline \multirow[t]{6}{*}{ Deep } & 1 & 2 & 3.63 & .89 \\
\hline & 2 & 2 & 4.45 & .77 \\
\hline & 3 & 37 & 2.77 & .93 \\
\hline & 4 & 90 & 3.43 & .90 \\
\hline & 5 & 199 & 3.74 & .84 \\
\hline & Total & 330 & 3.55 & .92 \\
\hline \multirow[t]{6}{*}{ Strategic } & 1 & 2 & 3.68 & .83 \\
\hline & 2 & 2 & 4.40 & .83 \\
\hline & 3 & 37 & 2.85 & 1.00 \\
\hline & 4 & 90 & 3.55 & .93 \\
\hline & 5 & 199 & 3.88 & .91 \\
\hline & Total & 330 & 3.68 & .98 \\
\hline \multirow[t]{6}{*}{ Surface } & 1 & 2 & 3.09 & .12 \\
\hline & 2 & 2 & 4.31 & .96 \\
\hline & 3 & 37 & 2.81 & .74 \\
\hline & 4 & 90 & 3.27 & .77 \\
\hline & 5 & 199 & 2.81 & .79 \\
\hline & Total & 330 & 2.94 & .81 \\
\hline
\end{tabular}

Table 8. One-Way Analysis of Variance (ANOVA) results of students' scores on mathematics learning approaches according to the mathematics achievement variable

\begin{tabular}{llllllll}
\hline & Source of Variance & Sum of squares & $\mathrm{df}$ & Mean square & $\mathrm{F}$ & $\mathrm{p}$ & $\eta^{2}$ \\
\hline \multirow{2}{*}{ Deep } & Between groups & 32.396 & 4 & 8.099 & 10.636 & .000 & 0.11 \\
& Within groups & 246.715 & 324 & .761 & & & \\
\multirow{5}{*}{ Strategic } & Total & 279.111 & 328 & & 10.428 & .000 & 0.11 \\
& Between groups & 36.178 & 4 & 9.045 & & & \\
& Within groups & 281.887 & 325 & .867 & 7.153 & .000 & 0.08 \\
& Total & 318.065 & 329 & & & \\
& Between groups & 17.480 & 4 & 4.370 & & & \\
& Within groups & 197.950 & 324 & .611 & & & \\
& Total & 215.431 & 328 & & & & \\
\hline
\end{tabular}


According to the results obtained with the "Tukey HSD" test conducted to determine at what grade levels the meaningful difference between students' mathematics achievement and mathematics learning approaches are; there is a significant difference between 3-4 and 3-5 levels from mathematics grades in deep and strategic sub-dimensions of learning approaches. In both sub-dimensions, this difference is in favour of 4 between 3-4 grades and 5 in 3-5 grades. In the surface learning approach, there is a significant difference between 3-4 and 45grades/marks. This difference is in the favour of 4 at the 3-4 level and 4 in the 4-5 level. From here, it is seen that students with a math grade of 4 prefer more surface learning than 3 and 5.

\section{Results regarding the second sub-problem}

a) Table 9 shows the results of independent sample t-test regarding whether students' mean scores of metacognitive awareness differ by gender.

Table 9. Independent sample t test results of the metacognitive awareness scores by gender

\begin{tabular}{llllllll}
\hline & Gender & $\mathrm{N}$ & $\overline{\mathrm{X}}$ & $\mathrm{sd}$ & $\mathrm{df}$ & $\mathrm{t}$ & $\mathrm{p}$ \\
\hline MAI TOTAL & Girl & 166 & 3.65 & .747 & 327 & .425 & .671 \\
& Boy & 164 & 3.61 & .791 & & & \\
\hline
\end{tabular}

As seen in Table 9, MAI scores of students do not show a significant difference according to gender ( $p>.05)$. Even though there is no significant difference between genders, female students' metacognitive awareness score averages are higher than male students.

b) Descriptive statistics of students' total point averages received from MAI by grade level are given in Table 10.

Table 10. Descriptive statistics of students' scores on the metacognitive awareness level by grade level

\begin{tabular}{lllll}
\hline Metacognitive Awareness Inventory & Grade & $\mathrm{N}$ & $\overline{\mathrm{X}}$ & sd \\
\hline & 6 & 134 & 3.82 & .600 \\
& 7 & 64 & 3.44 & .896 \\
& 8 & 132 & 3.54 & .817 \\
\hline
\end{tabular}

According to Table 10, it was determined that the average scores are $\bar{X}=3.82, \bar{X}=3.44$, and $\bar{X}=3.54$ for 6th, 7th, and 8th grade students, respectively. ANOVA results are shown in Table 11 to determine whether the students' average scores differ according to grade level.

Table 11. One-Way Analysis of Variance (ANOVA) results according to the grade level variable of students' scores on the metacognitive awareness levels

\begin{tabular}{lllllll}
\hline Source of Variance & Sum of squares & $\mathrm{sd}$ & Mean square & $\mathrm{F}$ & $\mathrm{p}$ & $\eta^{2}$ \\
\hline Within groups & 8,005 & 2 & 4.002 & 7.025 & .001 & 0.95 \\
Between groups & 185.719 & 326 & .570 & & & \\
Total & 193.723 & 328 & & & & \\
\hline
\end{tabular}

Table 11 shows the results of one-way analysis of variance as to whether students' metacognitive awareness scores differ according to grade level. According to the results obtained, there is a significant difference in students' metacognitive awareness as to grade level ( $\mathrm{p}<.05, \mathrm{~F}=7.025)$. "Tukey HSD" test, one of the post-hoc tests, was conducted to determine the grade levels of the students' meaningful differences in their metacognitive awareness. According to the results obtained; there is a significant difference between 6th and 
7th grade levels and 6th and 8th grade levels in terms of MAI scores. This difference is in both cases in favour of 6th grades.

c) Descriptive statistics of students' total score averages from MAI according to their mathematics achievement are given in Table 12.

Table 12. Descriptive statistics of students' maths scores regarding metacognitive awareness levels according to mathematics achievement

\begin{tabular}{llll}
\hline Maths scores & $\mathrm{N}$ & $\overline{\mathrm{X}}$ & $\mathrm{sd}$ \\
\hline 1 & 2 & 4.18 & .938 \\
2 & 2 & 4.39 & .856 \\
3 & 37 & 3.19 & .719 \\
4 & 90 & 3.43 & .873 \\
5 & 199 & 3.79 & .668 \\
Total & 330 & 3.63 & .768 \\
\hline
\end{tabular}

As seen in Table 12, the total score average of the students with math scores of 1 from MAI is $\bar{X}=4.18$, students with 2 is $\bar{X}=4.39$, students with 3 is $\bar{X}=3.19$, students with 4 is $\bar{X}=$ 3.43 , and students with 5 is $\overline{\mathrm{X}}=3.79$. One-way analysis of variance (ANOVA) results are shown in Table 13 to determine whether the students' total score averages differ according to their mathematics achievement.

Table 13. One-way Analysis of Variance (ANOVA) results according to the mathematics scores variable of the scores of students on the level of metacognitive awareness

\begin{tabular}{lllllll}
\hline Source of Variance & Sum of squares & sd & Mean square & F & p & $\eta^{2}$ \\
\hline Within groups & 17.929 & 4 & 4.482 & 8.261 & .000 & 0.90 \\
Between groups & 175.795 & 324 & .543 & & & \\
Total & 193.723 & 328 & & & & \\
\hline
\end{tabular}

Table 13 shows the results of one-way analysis of variance on whether students' metacognitive awareness scores differ according to their mathematics achievement. According to the results obtained, there is a significant difference in students' metacognitive awareness according to their mathematics achievement ( $\mathrm{p}<.05, \mathrm{~F}=8.261)$. "Tukey HSD" test, which is one of the post-hoc tests, was carried out to determine the math scores of the students' significant difference in their metacognitive awareness. Accordingly, there is a significant difference between students with a math scores of 3 and 5 , and students with a math grade of 4 and 5 in terms of their metacognitive awareness scores. When the average scores are analysed, this significant difference is in favour of those with a score of 5 between students whose scores are 3 or 5 , and in favour of those with a score of 5 between students whose scores are 4 or 5 . According to these results, it can be interpreted that as students' success in mathematics increases, so does their metacognitive awareness.

\section{Results regarding the third sub-problem}

For this sub-problem, Pearson Correlation analysis was conducted between mathematics learning approaches and MAI scores. The results are given in Table 14.

Table 14. Mathematics learning approaches correlation analysis of MAI relation

\begin{tabular}{|c|c|c|c|c|c|}
\hline & $\begin{array}{l}\text { Deep } \\
\text { Learning approaches }\end{array}$ & $\begin{array}{l}\text { Strategic } \\
\text { approaches }\end{array}$ & Learning & $\begin{array}{l}\text { Surface } \\
\text { approaches }\end{array}$ & Learning \\
\hline Correlation coefficient & $.469 *$ & $.468 *$ & & ,098 & \\
\hline Metacognitive Awareness & $\begin{array}{l}\mathrm{p} \\
, 000\end{array}$ & $\begin{array}{l}\mathrm{p} \\
, 000\end{array}$ & $\begin{array}{l}\mathrm{N} \\
330\end{array}$ & $\begin{array}{l}\mathrm{p} \\
, 078\end{array}$ & $\begin{array}{l}N \\
330\end{array}$ \\
\hline
\end{tabular}

$* \mathrm{p}<.05$ 
According to the findings in Table 14, there exists a positive and statistically significant relationship between deep learning approach and MAI [ $\mathrm{r}=-0.46, \mathrm{p}<.05]$; there is a positive and statistically significant relationship $[\mathrm{r}=0.46, \mathrm{p}<.05]$ between the strategic learning approach and MAI. No statistically significant relationship [ $\mathrm{r}=-0.098, \mathrm{p}>.05]$ was found between the surface learning approach and MAI. According to these findings, it can be said that, as students' metacognitive awareness increases, preference for deep and strategic learning approach increases.

For this purpose, simple linear regression analysis results are given in Table 15, Table 16 and Table 17.

Table 15. Simple Linear Regression Analysis results on predicting metacognitive awareness in deep mathematical learning approach

\begin{tabular}{lllllll}
\hline Variables & $\mathrm{B}$ & Standard error & $\beta$ & $\mathrm{R}^{2}$ & $\mathrm{t}$ & $\mathrm{p}$ \\
\hline Metacognitive Awareness & 1.503 & .219 & - & .220 & 6.861 & .000 \\
\hline
\end{tabular}

Table 16. Simple Linear Regression Analysis results on predicting the metacognitive awareness of the strategic mathematical learning approach

\begin{tabular}{lllllll}
\hline Variables & $\mathrm{B}$ & Standard error & $\beta$ & $\mathrm{R}^{2}$ & $\mathrm{t}$ & $\mathrm{p}$ \\
\hline Metacognitive Awareness & 1.507 & .233 & - & .219 & 6.480 & .000 \\
\hline
\end{tabular}

Table 17. Simple Linear Regression Analysis results regarding the predictability of metacognitive awareness on the surface mathematical learning approach

\begin{tabular}{lllllll}
\hline Variables & $\mathrm{B}$ & Standard error & $\beta$ & $\mathrm{R}^{2}$ & $\mathrm{t}$ & $\mathrm{p}$ \\
\hline $\begin{array}{l}\text { Metacognitive } \\
\text { Awareness }\end{array}$ & 2.574 & .217 & - & .010 & 11.878 & .000 \\
\hline
\end{tabular}

According to the table, MAI has a significant effect on learning approaches $(\mathrm{p}=.000)$. these students' Metacognitive awareness explains $22 \%$ of the variance in learning in deep, $21.9 \%$ of the strategic and $1 \%$ of the surface.

\section{Conclusion}

In this study, 6th, 7th and 8th grade students' mathematics learning approaches and their metacognitive awareness were examined in terms of variables of gender, grade level, and mathematics achievement. In the present study, it was detected the students used strategic learning approach the most when looking at the point averages of mathematics learning approaches. Students who preferred the deep learning approach above average also preferred the surface learning approach below the average. This finding is similar to those of these scholars: Darlington (2011), Matic and Katalenic (2013), Senemoğlu (2011) and GöktepeYıldız and Özdemir (2018), who conducted similar research at the undergraduate level,. Although there is no criterion for the study, the students participating in this study are those who show high success in the national entrance exam for high schools, which is of high stakes nature. In fact the schools participating in the study care about the success in the exams and they do their work in this direction. This may explain why students prefer the strategic learning approach for exam success. From the perspective of gender; in all sub-dimensions, students' scores differ significantly according to gender. While girls show deep and strategic learning approaches more, boys prefer surface learning approach. This finding is similar to the findings of Özgür and Tosun (2013). At the grade level, in the deep and strategic learning approaches, the average scores are ranged from high to low as Grade 6, Grade 8 and Grade 7. In the surface learning approach, this ranking is in the form of 7 th grade 8 classes and 6 grades. In other words; 7th grades prefer surface learning approach more than other grade 
levels; Grades 6 and 8 preferred deep and strategic learning approaches. This finding does not comply with the findings of Göktepe-Yıldız and Özdemir (2018), which conducted a similar study. This difference may be due to different study groups. In addition, there is a significant difference between 6th grade - 7th grade and 6th grade - 8th grade levels in all subdimensions of learning approaches. While this difference is in favour of Grade 6 in deep and strategic learning approach, it is in favour of Grade 8 in surface learning approach. According to these results, 6th grade students preferred to learn deep and strategic compared to 7 th grade and 8th grade students. This finding coincides with the finding in the study of Göktepe-Y1ldiz and Özdemir (2018) conducted at the secondary level, and the tendency of students to prefer the deep learning approach decreased as the grade level increased. In fact, as the classroom level of the learning environments in schools increases, it is expected that the deep learning approach will run the features of the work more (Göktepe-Yıldız \& Özdemir, 2018). In some studies, it has been observed that as the grade levels increase at the undergraduate level, the deep learning approach increases (Senemoğlu, 2011; Sezgin-Selçuk, Çalışkan \& Erol, 2007). However, the findings of this study at the secondary level revealed a different situation. This situation may be related to the exam anxiety that students may have considering the 8th grade students who prefer the surface learning approach compared to the 6th grade. In Turkey, it can be interpreted that students are trying to learn math in a surface way considering that they will take the exams at the grade level and to meet their exam needs. In addition, according to the results of this research, students' mathematics achievements differ significantly as regards their mathematical learning approaches. As the success of mathematics increases, it is seen that students prefer deep and strategic learning approaches. This is compatible with the results of similar studies (Bernardo, 2003; Diseth, 2002; Diseth \& Martinsen, 2002; Ekinci, 2009; Mayya, Rao \& Ramnarayan, 2004; Sezgin-Selçuk et al., 2007).

According to this research, the metacognitive awareness of the participating students is at a high level. It was observed that gender did not affect the metacognitive awareness levels of secondary school students. However, it was determined that the MAI score averages were higher in favour of female students. Dilci and Kaya (2012), Gürleyik and Sucu (2014), Özsoy and Günindi (2011) also did not find a significant difference at the undergraduate level by gender. In the literature, there are many studies examining the metacognitive awareness of individuals at different grade levels reporting a similar result regarding the gender variable (Hashempour, Ghoonsoly \& Ghanizadeh, 2015; Stewart, Cooper \& Molding, 2007; Özsoy, Çakıroğlu, Kuruyer \& Özsoy, 2010; Özsoy \& Günindi, 2011). However, Gürefe (2015), who conducted a similar study at the secondary level, observed a significant difference in favour of female students regarding gender. Again, Bağçeci, Döş and Sarıca (2011) found a statistically significant difference in favour of female students in undergraduate students. The difference of the groups studied may have caused this situation. In addition, it has been observed that the grade level makes a significant difference in metacognitive awareness. This difference was found in favour of 6th grade students compared to 7th and 8th grade students. In the literature, there are studies indicating that grade level makes a significant difference in metacognitive awareness (Baysal, Ayvaz, Çekirdekçi \& Malbeleği, 2013; Koç \& Kuvaç 2016; Özsoy \& Günindi, 2011), as well as studies indicating the opposite (Baba-Öztürk \& Güral, 2016; Deniz, Küçük, Cansız \& İşleyen, 2014; Gürefe, 2015; Gürleyük \& Sucu, 2014). Although there is a general consensus that the metacognitive awareness develops with age, mind development takes place in a social, cultural and linguistic environment that includes interaction with peers and adults (Larkin, 2000). Researchers have generally conducted studies on the concept of metacognition, measurement of metacognitive skills, and metacognitive awareness, but they did not focus on how the metacognitive processes develop with age. This suggests the idea that different variables are effective on metacognitive 
awareness. For this reason, it should be aimed to reveal the factors affecting individuals' metacognitive awareness levels in new research.

In the research, a significant relationship was found between mathematics achievement and metacognitive awareness. MAI scores were high, which would be in favour of students with high mathematics achievement. In studies conducted, it was found that there was a significant difference between academic achievement both in the course of mathematics and in other areas (Bağçeci, Döş \& Sarıca, 2011; Gürefe, 2016; Young \& Fry, 2008). Based on this, it can be interpreted that high metacognitive awareness may have a positive contribution to the increase of mathematics achievement. The findings of this study concur with those of some studies. For instance, Coutinho (2007) and Garner \& Alexander (1989) find that students with high metacognitive awareness perform better in mathematics than other students.

In the correlation analysis conducted to see the relationship between the metacognitive awareness and the mathematics learning approaches, it was observed that as the preference of students' deep and strategic learning approach increased, their metacognitive awareness increased. Regression analysis was carried out to see whether metacognitive awareness is a significant predictor of mathematics learning approaches. With regard to the output of this analysis, students' metacognitive awareness explains $22 \%$ of the variance in deep learning and $21.9 \%$ of the strategy and $1 \%$ of the surface. In other words, approximately $22 \%$ of students' deep and strategic learning approaches in mathematics learning approaches were explained by their awareness of using metacognitive strategies.

The research was conducted with students in two public schools in the Central Anatolia Region. For this reason, the sample group should be expanded to include different regions and schools of Turkey in order to generalize the findings and make clearer interpretations. In this study, the level of students ' cognitive awareness and their approach to learning mathematics and the question of which variables are affected were sought. Alt and Raichel (2020) stated that reflective daily use can be an important strategy to increase students' metacognitive awareness. In addition, the study shows that students can develop self-regulation competencies and different individualized learning strategies depending on their reflective daily use. Considering the place and importance of the metacognitive awareness in teaching, it is necessary to increase the efficiency of these variables and to reveal the situations in which these variables are affected. This can be realized by new studies yet to be carried out in order for the mathematical learning approaches of the students to be more effective and efficient. In this process, different data collection tools and methods can be employed to reach more detailed and rich information.

\section{References}

Akın, A. (2006). Relationships between achievement goal orientations, metacognitive awareness, parenting styles and academic achievement. (Unpublished doctoral thesis). Sakarya University, Sakarya.

Akın, A., Abacı, R., \& Çetin, B. (2007). The validity and reliability of the Turkish version of the metacognitive awareness inventory. Educational Sciences: Theory \& Practice, 7(2), 671-678.

Altindag, M., \& Senemoğlu, N. (2013). Metacognitive Skills Scale. Hacettepe University Journal of Education, 28(1), 15-26.

Alt, D. \& Raichel, N. (2020). Reflective journaling and metacognitive awareness: insights from a longitudinal study in higher education, Reflective Practice, 21(2), 145-158. 
Altıok, S., Başer, Z., \& Yükseltürk, E. (2019). Enhancing metacognitive awareness of undergraduates through using an e-educational video environment. Computers \& Education, 139, 129-145.

Aral, N., Gürsoy, F. \& Can-Yaşar, M. (2012). Investigating the effect of the implementation with puzzle educational materials on the fifth. Journal of Ankara Health Sciences, $1(1), 157-170$.

Baba-Öztürk, M., \& Güral, M. (2016). Analysis of prospective preschool teachers' metacognitive awareness levels in terms of various variables: OMU sample. Electronic Turkish Studies, 11(19), 107-132.

Bağçeci, B., Döş, B., \& Sarıca, R. (2011). An analysis of metacognitive awareness levels and academic achievement of primary school students. Mustafa Kemal University Journal of Social Sciences Institute, 8(16), 551-566.

Baltac1, S., Y1ldiz, A. \& Özcakir, B. (2016). The relationship between metacognitive awareness levels, learning styles, genders and mathematics grades of fifth graders. Journal of Education Learning, 5(4), 78-89.

Baysal, N.Z., Ayvaz, A., Çekirdekçi, S., \& Malbeleği, F. (2013). Examination of scientific creativity level of fourth grade students in terms of several variables. M.U. Journal of Educational Sciences, 37, 68-81.

Bernardo. A. B. I. (2003). Approaches to learning and academic achievement of Filipino students. Journal of Genetic Psychology, 164(1), 101-114.

Beydoğan, Ö. (2007). The functions of concept maps and schemein the deep learning and surface learning. Milli Ĕgitim Dergisi [Journal of National Education], 173, 258-270.

Biggs, J. (1987). Student Approaches to Learning and Studying. Melbourne: Australian Council for Educational Research.

Biggs, J. (1988). Assessing student approaches to learning. Australian Psychologist, 23(2), 197-206.

Biggs, J. (1993). What do inventories of students' learning processes really measure? A theoretical review and clarification. British Journal of Educational Psychology, 63, 319.

Biggs, J. (1994). Approaches to learning: Nature and measurement of. In T. Husen \& T.N. Postlethwaite (Eds.), The international encyclopedia of education (pp. 319- 322). Oxford: Pergamon.

Biggs, J.B. (2001). Enhancing learning: A matter of style or approach? In R.J. Sternberg \& L. Zhang (Eds.), Perspectives on thinking, learning, and cognitive styles (pp. 73-102). Mahwah: Lawrence Erlbaum Associates.

Biggs, J. B., Kember, D., \& Leung, D.Y.P. (2001). The revised two-factor study process questionnaire: R-SPQ-2F. British Journal of Educational Psychology, 71, 133-149.

Biggs, J., \& Tang. C. (2011). Teaching for Quality Learning at University: What the Student Does. 4th Edition. McGraw-Hill: Society for Research into Higher Education (SRHE) and Open University Press.

Blakey, E. \&Spence, S. (1990). Developing metacognition, ERIC Clearinghouse on Information Resources Syracuse.

Brown, A.L. (1980). Metacognitive development and reading. In R.J. Spiro, B. Bruce, \& W. Brewer (Eds.), Theoretical issues in reading comprehension. (pp. 453-481) Hillsdale, NJ: Lawrence Erbaum.

Bulut, A.S., Yildiz, A., \& Baltac1, S. (2020). A comparison of mathematics learning approaches of gifted and non-gifted students. Turkish Journal of Computer and Mathematics Education (TURCOMAT), 11 (2), 461-491.

Büyüköztürk, Ş. (2015). Data analysis handbook for social sciences (10th edition). Ankara: Pegem Academy Publishing. 
Byrne, M., Flood, B., \& Willis, P. (2002). The relationship between learning approaches and learning outcomes: A study of Irish accounting students. Accounting Education, 11(1), 27-42.

Cuthbert, P.F. (2005). The student learning process: learning styles or learning approaches. Teaching in Higher education, 10(2), 235-249.

Coutinho, S. A. (2007). The relationship between goals, metacognition, and academic success. Educate, 7(1), 39-47.

Çakıroğlu, A. (2007). The effect of metacognitive strategy training on improving the achievement level of students having low achievement levels of reading comprehension. (Unpublished doctoral thesis). Gazi University, Ankara.

Darlington, E. (2011). Approaches to learning of undergraduate mathematicians. The Day Conference of British Society of Research on Learning of Mathematics (BSRLM) Conference. Oxford, England.

Deniz, D., Küçük, B., Cansız, Ş., Akgün, L., \& İşleyen, T. (2014). Examining metacognitive awareness of prospective secondary school mathematics teachers in terms of some variables. Kastamonu Education Journal, 22(1), 305-320.

Desoete, A., Roeyers, H., \& Buysse, A. (2001). Metacognition and mathematical problem solving in grade 3. Journal of Learning Disabilities, 34(5), 435-447.

Dilci, T., \& Kaya, S. (2012). Examination of meta-cognitive awareness levels of class teachers teaching 4th and 5th grades in terms of various variables. SDU Faculty of Arts and Sciences Journal of Social Sciences, 27, 247-267.

Diseth, A. (2001). Validation of a Norwegian version of the approaches and study skills inventory for students (ASSIST): Application of structural equation modelling. Scandinavian Journal of Educational Research, 45(4), 381-394.

Diseth, A. (2002). The relationship between intelligence, approaches to learning and academic achievement. Scandinavian Journal of Educational Research, 46(2), 219230.

Diseth, A., \& Martinsen, O. (2002). Approaches to learning, cognitive style and motives as predictors of academic achievement. Educational Psychology, 23(2), 195-207.

Dunslosky, J., \& Thiede, K. W. (1998). What makes people study more? An evaluation of factors that affect self-paced study. Acta Psychologica, 98, 37-56.

Ekinci, N. (2009). Learning approaches of university students. Education and Science, 34(151), 74-88.

Ellez, M., \& Sezgin, G. (2002). Pre-service teachers' approaches to learning. V. National Science and Mathematics Education Congress Proceedings Book. Ankara.

Entwistle, N. J. (1981). Styles of learning and teaching. Chichester, UK: Wiley.

Entwistle, N. (1991). Approaches to learning and perceptions of the learning environment. Higher Education, 22, 201-204.

Entwistle, N.J. (1997). Reconstituting approaches to learning: A response to webb. Higher Education, 33, 213-218.

Entwistle, N., McCune, V., \& Walker, P. (2001). Conceptions, styles, and approaches within higher education: Analytical abstractions and everyday experience. In R.J. Sternberg, \& L.-F Zhang (Eds.), Perspective of think, learning, and cognitive styles (pp. 103136). Mahwah, NJ: Lawrance Erlbaum.

Flavell, J.H. (1979). Metacognition and cognitive monitoring. American Psychologist, 34(10), 906-911.

Forrest-Pressley, D. L., \& Waller, T. G. (1984). Cognition, metacognition and reading. New York : Springer-Verlag.

Fraenkel, J. R., Wallen, N.E., \& Hyun, H. H. (2012). How to design and evaluate research in education. New York: Mc Graw Hill. 
Garner, R., \& Alexander, P.A. (1989). Metacognition: Answered and unanswered questions. Educational Psychologist, 24, 143-158.

Gürefe, N. (2015). Investigation of metacognitiveawareness of secondary school students in terms of some variables. The Journal Of International Educational Science, 2(5), 237246.

Gürleyük, G.C., \& Sucu, H.Ö. (2014). Analyzing metacognitive awareness level of university students in terms of specific variables (Erciyes university sample). Milli Ĕgitim Dergisi [Journal of National Education], 44(201), 109-124.

Hacker, D.J. (1998). Metacognition: definitions and empirical foundations. In: D.J. Hacker, J. Dunlosky, \& A.C. Graesser (Eds.). Metacognition in educational theory and practice (pp. 1-24). Mahwah, NJ: Erlbaum.

Hair, J. F., Black, W.C., Babin, B. J., Anderson, R. E., \& Tatham, R. L. (2013). Multivariate Data Analysis. London: Pearson Education Limited.

Harlen, W., \& James, M., (1997). Assessment and learning: differences and relationships between formative and summative assessment. Assessment in Education: Principles, Policy \& Practice, 4(3), 365-380.

Hashempour, M., Ghoonsoly, B., Ghanizadeh, A. (2015). A study of translation of students' self- regulation and metacognitive awareness in association with their gender and educational level. International Journal of Comparative Literature\&Translation Studies, 3(3), 60-69.

Heikkilla, A., \& Lonka, K. (2006). Studying in higher education: Students' approaches to learning, self-regulation, and cognitive strategies. Studies in Higher Education, 31(1), 99-117.

İlhan, M., Çetin, B., \& Kılıç, M.A. (2013). Development of mathematics learning approaches scale (mlas): validity and reliability study. Bartin University Journal of Faculty of Education, 2(2), 113 -145.

Karasar, N. (2005). Scientific research method. Ankara: Nobel Publishing.

Koç, I., \& Kuvaç, M. (2016). Pre-service science teachers' metacognitive awareness levels. European Journal of Education Studies, 2(3), 43-63.

Köse, E. (2013). Bilimsel araştırma modelleri [Scientific research models]. R.Y. Kincal (Ed.). Bilimsel araştırma yöntemleri[Scientific research methods] (p.99-123). Ankara: Nobel Publishing House.

Larkin, S. (2010). Metacognition in young children. New York: Routledge.

Lee C.B., Teo, T., \& Bergin, D. (2009). Children's use of metacognition in solving everyday problem: an initial study from an Asian context. The Australian Educational Researcher Journal, 36(3), 89-104.

Lucas, U. (2001). Deep and surface approaches to learning within introductory accounting: A phenomenographic study. Accounting Education: An International Journal, 10(2), 161-184.

Makinen, J. (2003). University students' general study orientations: theoretical background, measurements and practical implications. University of Turku: Annales Universitatis Turkuensis.

Martini, R., \& Shore, B. M. (2008). Pointing to parallels in ability related differences in the use of metacognition in academic and psychomotor tasks. Learning and Individual Differences, 18, 237-247.

Marton, F. (1983). Beyond individual differences. Educational Psychology, 3, 289-303.

Marton, F., \& Saljo, R. (1976a). On qualitative differences in learning I: -Outcome \& process. British Journal of Educational Psychology, 46, 4-11. 
Marton, F., \& Saljo, R. (1976b). On qualitative differences in learning -II: Outcome as a function of the learner's conception of the task. British Journal of Educational Psychology, 46, 115-127.

Marton, F., \& Saljo, R. (1997). Approaches to learning. In F. Marton, D. Hounsell, \& N. Entwistle (Eds.) The experience of learning (pp. 39-58). Edinburgh Scoottish Academic Press.

Matic, L.J., Matic, I., \& Katalenic, A. (2013). Approaches to learning mathematics in engineering study program. In M. Pavlekovic, Z. Kolar-Begovic, \& R. Kolar-Super (Eds.) Mathematics teaching for the future (pp. 186-195). Element.

Mayya, S.S., Rao, A.R., \& Ramnarayan, K. (2004). Learning approaches, learning difficulties and academic performance of undergraduate students of physiotherapy. The Internet Journal of Allied Health Science and Practice, 2(4), 1-6.

Meichenbaum, D., Burland, S., Gruson, L., \& Cameron, R. (1985). Metacognitive assessment. In S. Yussen (Ed.), The growth of reflection in children (pp.3-30), Toronto: Academic Press.

Newble, D. I., \& Entwistle, N. J. (1986). Learning styles and approaches: Implications for medical education. Medical Education, 20, 162-175.

Özsoy, G., \& Günindi, Y. (2011). Prospective preschool teachers' metacognitive awareness. Elementary Education Online, 10(2), 430-440.

Özsoy, G., Çakıroğlu, A., Kuruyer, H.G., \& Özsoy, S. (2010). Examination of the metacognitive awareness levels of classroom teacher candidates in terms of some variables. 9th Class Teacher Education Symposium, Elazığ.

Özgür, H., \& Tosun, N. (2013). Examination the deep and surface learning approaches of preservice teachers in terms of some variables. Mehmet Akif Ersoy University Journal of Education Faculty, 1(24), 113-125.

Pressley, M., \& Ghalata, E.S. (1989). Metacognitive benefits of taking a test for children and young adolescents. Journal of Experimental Child Psychology, 47, 430-450. http://dx.doi.org/10.1016/0022-0965(89)90023-4.

Ramsden, P. (1979). Student learning and perceptions of the academic environment. Higher Education, 8, 411-27.

Ramsden, P. (2000). Learning to teaching in higher education. London: New York Routhladge Falmer.

Reid, W.A., Duvall, E., \& Evans, P. (2007). Relationship between assessment results and approaches to learning and studying in year two medical students. Medical Education, 41(8), 754-762.

Scherer, R. F., Luther, D. C., Wiebe, F. A., \& Adams, J. S. (1988). Dimensionality of coping: Factor stability using the ways of coping questionnaire. Psychological Reports, 62(3), 763-770.

Schmeck, R. R. (1988). An introduction to strategies and styles of learning. In R. R. Schmeck (Ed.), Learning strategies and learning styles (pp. 53-81). New York: Plenum Press.

Selçuk, G. S., Çalışkan, S., \& Erol, M. (2007). Evaluation of learning approaches for prospective physics teachers. Gazi University Journal of Gazi Education Faculty, 27(2), 25-41.

Senemoğlu, N. (2005). Gelişim öğrenme ve ögrretim kuramdan uygulamaya [From developmental learning and teaching theory to practice]. 12. Edition, Gazi Publishing House, Ankara.

Senemoğlu, N. (2011). College of education students' approaches to learning and study skills. Education and Science, 36(160), 65-80.

Stewart, P. W., Cooper. S. S., \& Moulding, L. R. (2007). Metacognitive development in professional educators. The Researcher, 21(1), 32-40. 
Trigwell, K., \& Prosser, M. (1991). Improving the quality of student learning: The influence of learning context and student approaches to learning on learning outcomes. Higher Education, 22, 251-266.

Trigwell, K., Prosser, M., \& Waterhouse, F. (1999). Relations between teachers' approaches to teaching and students' approaches to learning. Higher Education, 37(1), 57-70.

Uckun, C.G., Demir, B., \& Yuksel, A. (2012). Examining metacognitive awareness of academic directors working in vocational high schools: The case of Kocaeli University. Kocaeli University Journal of Social Sciences, 24, 51-74.

Vadhan, V., \& Stander, P. (1994), Metacognitive ability and test performance among college students. The Journal of Psychology, 128(3), 307-309.

Volet, S. E. (1991). Modeling and coaching of relevant metacognitive strategies for enhancing university students' learning. Learning and Instruction, 1, 319-336.

Weinstein, C. E., \& Mayer, R. E. (1986). The teaching of learning strategies. In Wittrock, M.C. (Ed.). Handbook of Research on Teaching (pp. 315-327). New York: Macmilian Publishing Company.

Yıldız, S. G., \& Özdemir, A. Ş. (2018). Determining the approaches to learning mathematics of middle school students. Elementary Education Online, 17(3), 1378-1401.

Yıldız, A., Baltacı, S., \& Kuzu, O. (2018). The investigation of students' cognitive and metacognitive competencies according to different variables. European Journal of Education Studies, 4(10), 81-98.

Young, A., \& Fry, J. D. (2008). Metacognitive awareness and academic achievement in college students. Journal of the Scholarship of Teaching and Learning, 8(2), 1-10. 